\title{
Construction and empirical analysis of the indicators of college students' basic information ability for employability
}

\author{
Maylin Yen* \\ Department of Education \\ National Hsinchu University of Education, Taiwan \\ E-mail: meier@mail.nhcue.edu.tw \\ *Corresponding author
}

\begin{abstract}
This study investigated the basic information ability required of college students to be employable in the information technology-centered industrial environment. The researcher interviewed department heads at the National Hsinchu University of Education as well as computer cram school instructors and human resource managers to identify the information abilities expected of students. These preliminary indicators were then revised into a five-major information ability dimension 58-item "Indicators of college students' basic information ability for employability" by administering the three-round Delphi method survey to 17 managers in the public and private sector as well as industry experts throughout Taiwan. These indicators were then provided to college students from 17 colleges associated with regional information centers in Taoyuan, Hsinchu, and Miaoli for self-assessment. A total of 2, 379 effective questionnaires were collected. The "Indicators of college students' basic information ability for employability" can be used by relevant universities to help students improve information related abilities.
\end{abstract}

Keywords: College students; Employability; Information ability; Indicators

Biographical notes: Maylin Yen is currently a doctoral student at Department of Education, National Hsinchu University of Education in Taiwan. She is also a librarian in the university library, since 2004, where she joined Professor Lin's "Taiwan e-teacher professional development Project" and co-worked on the developing of the online platform and professional training courses for inservice K-12 teachers. Her research interests include information literacy, elearning and character education.

\section{Introduction}

With the proliferation of higher learning over the past decade in Taiwan, college education has transformed from belonging to the elite, to the general public, and now to the masses (Sun, 2005). This proliferation is in response to the expectations and needs of society. Although it may seem to create equality in educational opportunities, it may be argued that an increase in quantity could lead to a decrease in quality.

To address this problem, the Ministry of Education promulgated the "Teaching Excellence Project" in 2004 to promote more superior educational functions in colleges and universities through changes to the overall system and by encouraging competition for funding and awards. This project is further expected to improve student quality and increase international competitiveness for colleges as a whole (Chi \& Sun, 2009). Since 
its induction, the program has seen improvements in instructor education, innovations in course content, and broadening of student learning. The program was especially effective and active in improving student abilities. From the establishment of basic core ability indicators at colleges to career planning after graduation, every college worked diligently to provide a sustainable career ability path for students. Because of the development of an information technology society, basic information abilities have become explicit conditions required for college and the workplace.

Furthermore, college education has become increasingly career-oriented and colleges are advising students to obtain internship opportunities in companies to increase related experience and earn certifications to boost their competitiveness while in college (Chen, 2008). As college education becomes a common denominator, companies view certifications as a primary and effective way to distinguish and prove proficiency. Aside from professional discipline certifications, certifications in basic abilities, such as English and information, have also become an integral part of college students' essential skills for employability from the perspective of college education. Since the inception of the "Teaching Excellence Project" colleges have also established related basic ability thresholds for graduating students.

Changes and trends in the career market drive educational reforms. This study investigated the skills for employability expected of college students in this era of information revolution. This study also investigated the basic information technology application skills expected of college students (explicit basic skills), and how students perform in this respect, to help college students understand their current abilities and to provide a reference for schools to develop courses for integrating information skills with employment abilities.

\section{Literature review}

\subsection{Learning transfer}

Learning transfer refers to "the influence of acquired knowledge, action skills, emotions, and attitudes to new learning" (Chou, 2009). Learning transfer is also known as training transfer, which is the phenomenon whereby learning outcomes are expanded or categorized (Chang, 1989). In the workplace, learning transfer is defined as the effective application of knowledge and abilities learned in an educational setting in the workplace (Broad, 1997). Learning transfer is frequently applied in several fields, such as psychology, philosophy, school-based education, adult education, and career or professional education. In the United Kingdom, learning transfer in the context of social work education is considered a core principle of professional certification. In the information age, knowledge and abilities or skills are rapidly and economically transferred to new work environments using technology, and this has become a topic of increasing importance. Learning transfer is undoubtedly a core goal in teaching and training in both educational and work contexts. Although it is deemed essential, it is not an easily-attainable goal (Tsai, 2002).

\subsection{Employability}

Employability is commonly developed through learning. British scholars Harvey, Locke, and Morey (2002) have defined the essence of employability as "the development of abilities to obtain work, maintain work, and work efficiently and well through one's 
learning experiences." In other words, employability refers to the ability to obtain and continue to complete work (Lio, Chiou, \& Hu, 2006, p. 6).

Pool and Sewell (2007) suggested that employability refers to the possession of a series of skills, knowledge, career understanding, and personal attitudes to facilitate the selection and maintenance of a satisfactory job and the success thereof.

Regarding the employability levels college students must possess and how this employability can be discovered and studied during college education, in 2006, the National Youth Commission, Executive Yuan published the "Graduating University and College Student Employability Survey Report" and surveyed graduating college students and enterprise employers for importance rankings of employability skills. The report identified eight core employability abilities, namely good work attitudes, stability and stress management or resistance, expression and communication skills, professional knowledge and skills, willingness to learn and moldability, cooperation or teamwork skills, basic computer application skills, and problem identification and solving abilities (Lio, Chiou, \& Hu, 2006, p. 6).

Foreign studies have classified employability into core employability and employability ability or skill structures. British studies have classified core employability into three portions, namely attitudes and personal traits conducive to employment; selfmarketing and career management skills; willingness to learn; and reflection on one's learning (Harvey, Locke, \& Morey, 2002). Based on the employability skills framework developed in Australia, core employability skills can be classified into eight scopes: communication skills, teamwork skills, problem solving skills, creativity and improvement skills, planning and organization skills, self-management skills, learning skills, and technology skills (Curtin, 2004).

Based on a psychological perspective, Chang proposed that skills can be classified into psychological skills and functional skills. Psychological skills are based on personal genetics and are manifested through the application of experience, learning, and the allocation of knowledge, as well as adaptations to change for the consideration and solution of problems. Functional skills, by contrast, refer to skills that can be demonstrated through behaviors based on potential learning, and are otherwise known as potential or orientated skills (Chang, 2008).

These studies have shown that among the employability skills required in the workplace or in a career, functional skills are easily identifiable or demonstrated and are mostly learned. The basic information abilities for employability investigated in this study are identifiable or explicit skills and are essential in an information-based society. Because of the learning transfer trend, if these skills can be familiarized, students can be empowered to accommodate continuously changing and innovating information skills.

\section{Research design and implementation}

This study was divided into two stages. Information skills essential to college students were first collected to draft preliminary indicators prior to the first stage. The researcher conducted a preliminary analysis of college students' essential information skills through data analysis and interviews at the National Hsinchu University of Education in the first semester of 2009 from three dimensions: schools, computer cram schools, and industry. The researcher interviewed 12 department heads, 1 computer cram school teacher, and 5 human resource managers to identify their understanding and requirements of college 
students regarding information skills. The results of the interviews, coupled with related information, were used to draft a list of preliminary indicators.

The list of preliminary indicators was used in the first stage for expert consultation, in which 5 major dimensions and 58 indicators of college student basic information ability for employability were created. In the second stage, the indicators were compiled into an online questionnaire and administered to college students at 22 colleges and universities associated with regional resource centers in Taoyuan, Hsinchu, and Miaoli to assess to what extent the information ability level of students fulfilled the indicators. Students from 17 colleges and universities participated in the study, yielding 2,378 effective questionnaires.

\subsection{Stage one-Drafting the indicators of college students' basic information ability for employability}

\subsubsection{Research method-The Delphi method survey}

This study defines college students' basic information ability for employability as information application abilities required in the future workplace for workers in noninformation occupations in the public and private sector. These basic information abilities seek to fulfill the demands of the workplace.

Based on the results of the preliminary study, the researcher developed dimensions and indicators that define core information skills expected of college students in July 2010. From August to November 2010, the researcher interviewed and consulted 17 experts and scholars, including teacher cultivation and information-related experts and instructors, public and private sector managers, and human promotion and resource department experts. The indicators were formed over three rounds. In the preliminary stage, the researcher identified four major dimensions, namely Office use, Layout and graphic design, Web site development, and Computer and Internet skills. These were then further divided into 10 items and 60 indicators and presented to the experts to gauge their appropriateness.

\subsubsection{Data analysis method}

The indicators were evaluated using a six point scale to gauge their relative importance and were modified, added, or removed using descriptive statistical analysis. Finally, mean and interquartile range were used to determine whether these indicators were critical and whether expert opinions were concentrated or centralized. The experts also provided their open suggestions on the dimensions, categories, and indicators to serve as reference for modification, addition, and removal.

\subsection{Stage two-Research of college students' basic information ability for employability}

\subsubsection{Research method-Survey}

An information ability self-assessment questionnaire was developed based on the "indicators of college students' basic information ability for employability" developed in Stage One and administered to a population of college students at 22 colleges and 
universities associated with regional resource centers in Taoyuan, Hsinchu, and Miaoli. The questionnaire was administered online between March 11 and April 11, 2011 to 17 universities and colleges and technology and vocational schools: CYCU, NCTU, NTHU, CHU, YZU, HCU, CGU, NTSU, NHCUE, NUU, KNU, MCU (the above are universities and colleges), CUTE, CYU, YPU, NANYA, and THIT (the above are technology and vocational schools). A total of 2,378 effective questionnaires were obtained from this study. The questionnaire mainly explored the level of proficiency college students demonstrate regarding basic information skills, as well as the influence of different personal background variables (school type, gender, and school year) on levels for various dimensions of information skills (Office use, Layout and graphic design, Web page development, Computers and the Internet, and Digital media).

\subsubsection{Data analysis}

In this stage, a self-assessment questionnaire using a six point scale was created based on five dimensions, 10 items, and 58 indicators developed by the experts. A basic information section was also added and included information about participants' schools, departments, school year, and gender and other basic background variables. The Chinese version of SPSS for Windows 12 was used to conduct descriptive statistical analysis and two-way analysis of variance.

\section{Research results}

The results of the study are presented in two parts.

\subsection{Overall results of developing the various dimensions for indicators in theindicators of college students' basic information ability for employability}

The 17 experts marked the five-dimension and 10-item indicators of college students' basic information ability for employability as extremely important (total average value = 5.35). The mean for Office use was highest and its quartile range was lowest; this was followed by Web page development skills, Computers and the Internet, Layout and graphic design, and Digital media. Among the 10 items, the average values of Data spreadsheets for Office use were highest, followed by Internet application and information safety, and finally Powerpoint application.

In the third round of the Delphi survey, the experts incorporated the Digital media dimension and removed the preliminary Flash item from the Web page development skills dimension. The experts suggested that Flash should be considered professional knowledge and thus should not be classified as a basic information ability for employability. By contrast, the newly added Digital media was recommended by the public sector experts, who believed that, in the employment market, people come into contact with various activities, which must be recorded and the pictures and films publicized; especially in an Internet environment, photos and films can provide the most realistic and authentic evaluation and review. Therefore, this indicator was added. The overall result is presented in Table 1. 
Table 1

Analysis statistics for indicator mean values of indicators of college students' basic information ability for employability as gauged by experts

\begin{tabular}{|c|c|c|c|c|c|c|c|c|c|}
\hline \multirow[t]{2}{*}{ Dimensions } & \multirow[t]{2}{*}{ Themes } & \multirow{2}{*}{$\begin{array}{l}\text { Number of } \\
\text { Indicators }\end{array}$} & \multirow{2}{*}{$\begin{array}{l}\text { Overall } \\
\text { mean } \\
\text { values }\end{array}$} & \multirow{2}{*}{$\begin{array}{c}\text { Rank } \\
\text { ing }\end{array}$} & \multicolumn{4}{|c|}{$\begin{array}{l}\text { Overall interquartile } \\
\text { range distribution }\end{array}$} & \multirow{2}{*}{$\begin{array}{c}\text { Rank } \\
\text { ing }\end{array}$} \\
\hline & & & & & 0 & 0.5 & 1 & $>1$ & \\
\hline \multirow{4}{*}{ Office use } & Text processing & 6 & 5.40 & 5 & 3 & 2 & 1 & 0 & 4 \\
\hline & $\begin{array}{l}\text { Powerpoint } \\
\text { Applications }\end{array}$ & 6 & 5.52 & 3 & 3 & 3 & 0 & 0 & 2 \\
\hline & $\begin{array}{c}\text { Data } \\
\text { spreadsheets }\end{array}$ & 7 & 5.60 & 1 & 4 & 3 & 0 & 0 & 1 \\
\hline & \multicolumn{3}{|c|}{ Average value 5.50} & & & & & & \\
\hline \multirow{4}{*}{$\begin{array}{c}\text { Layout and } \\
\text { Graphic } \\
\text { Design }\end{array}$} & Image editing & 4 & 5.21 & 8 & 0 & 3 & 1 & 0 & 9 \\
\hline & Image design & 7 & 5.09 & 10 & 0 & 6 & 1 & 0 & 8 \\
\hline & \begin{tabular}{|l|} 
Digital layout \\
\end{tabular} & 6 & 5.34 & 6 & 1 & 5 & 0 & 0 & 5 \\
\hline & \multicolumn{3}{|c|}{ Average value 5.21} & & & & & & \\
\hline \multirow{2}{*}{$\begin{array}{c}\text { Web page } \\
\text { development } \\
\text { skills }\end{array}$} & $\begin{array}{c}\text { Web site } \\
\text { planning and } \\
\text { development }\end{array}$ & 5 & 5.43 & 4 & 0 & 5 & 0 & 0 & 6 \\
\hline & \multicolumn{3}{|c|}{ Average value 5.43} & & & & & & \\
\hline \multirow{3}{*}{$\begin{array}{l}\text { Computers } \\
\text { and the } \\
\text { Internet }\end{array}$} & \begin{tabular}{|c|} 
Computer \\
hardware \\
understanding \\
and \\
maintenance \\
\end{tabular} & 5 & 5.23 & 7 & 0 & 5 & 0 & 0 & 7 \\
\hline & $\begin{array}{c}\text { Internet } \\
\text { application and } \\
\text { information } \\
\text { safety }\end{array}$ & 7 & 5.54 & 2 & 4 & 2 & 1 & 0 & 3 \\
\hline & \multicolumn{3}{|c|}{ Average value 5.39} & & & & & & \\
\hline \multirow[t]{2}{*}{ Digital media } & $\begin{array}{c}\text { Digital media } \\
\text { application }\end{array}$ & 5 & 5.12 & 9 & 0 & 2 & 3 & 0 & 10 \\
\hline & \multicolumn{3}{|c|}{ Average value 5.12} & & & & & & \\
\hline Total/Overal & 1 Mean Values & 58 & 5.35 & & & & & & \\
\hline
\end{tabular}

\subsection{Analysis of college student's basic information abilities for employability}

\subsubsection{Description of participants}

Table 2 presents the background information and corresponding percentages of the participants in this study. The chi-square goodness of fit test was used to analyze the percentage of the participants' gender, as well as the school type and percentage of the gender and school type of all students in Taiwan. The results indicated that there were no significant differences between the percentage of the participants' gender and school type and the percentage of the gender and school type of all students in Taiwan. This shows that the gender and school type of the sample population are representative of students in Taiwan. 
Table 2

A comparison between the background data of college students in the sample population and those of college students in Taiwan

\begin{tabular}{|c|c|c|c|c|c|}
\hline & & $\begin{array}{l}\text { Number of } \\
\text { students in } \\
\text { the sample } \\
\text { population }\end{array}$ & Percentage & $\begin{array}{c}\text { Number } \\
\text { of } \\
\text { students } \\
\text { in Taiwan }\end{array}$ & Percentage \\
\hline \multirow[t]{3}{*}{$\begin{array}{c}\text { School } \\
\text { type }\end{array}$} & $\begin{array}{l}\text { Universities } \\
\text { and Colleges }\end{array}$ & 1468 & 61.73 & 458732 & 55.73 \\
\hline & $\begin{array}{c}\text { Technology } \\
\text { and } \\
\text { Vocational } \\
\text { Schools }\end{array}$ & 910 & 38.27 & 364468 & 44.27 \\
\hline & Total & 2378 & 100 & 823200 & 100 \\
\hline \multirow[t]{3}{*}{ Gender } & Male & 1031 & 43.36 & 423222 & 51.41 \\
\hline & Female & 1347 & 56.64 & 399978 & 48.59 \\
\hline & Total & 2378 & 100 & 823200 & 100 \\
\hline
\end{tabular}

\subsubsection{Level of college students' basic information abilities for employability}

The results of the one-sample t-test showed that, based on a standard value of 3.5 points for the t-test, only Web page development skills are significantly lower than $3.5(\mathrm{M}=$ $3.26, p=.000<.05)$. This indicates that, according to their own assessment, the Web page development skills of the college students surveyed in the study were the weakest among their five information ability dimensions. Their ratings for layout and graphic design were higher than 3.5 but were not significant, indicating that this indicator is only better than their Web page development skills. The remaining three skills were significantly higher than 3.5 .

Table 3

A comparison between experts' and college students' rankings of dimensions and items for information skills

\begin{tabular}{|c|c|c|c|}
\hline Dimensions & items & Experts & College students \\
\hline \multirow{3}{*}{ Office use } & Text processing & 5 & 4 \\
\hline & Power point application & 3 & 1 \\
\hline & Data Spreadsheet & 1 & 7 \\
\hline \multirow{3}{*}{$\begin{array}{c}\text { Layout and graphic } \\
\text { design }\end{array}$} & Image editing & 8 & 6 \\
\hline & Image design & 10 & 8 \\
\hline & Digital layout & 6 & 9 \\
\hline Web site development & $\begin{array}{c}\text { Web site planning and } \\
\text { development }\end{array}$ & 4 & 10 \\
\hline \multirow{2}{*}{$\begin{array}{l}\text { Computers and the } \\
\text { Internet }\end{array}$} & $\begin{array}{c}\text { Computer hardware } \\
\text { understanding and } \\
\text { maintenance }\end{array}$ & 7 & 5 \\
\hline & $\begin{array}{l}\text { Internet application and } \\
\text { information safety }\end{array}$ & 2 & 2 \\
\hline Digital media & $\begin{array}{c}\text { Digital media } \\
\text { application }\end{array}$ & 9 & 3 \\
\hline
\end{tabular}


When compared to Table 1 , it is evident that there is a difference between the self-appraised basic information application skills of college students and the ability level the experts expect of them, as shown in Table 3. The experts agreed that the Office use dimension was of prime importance for employability, especially the data spreadsheet item. In reality, however, college students showed the weakest data spreadsheet skills within the Office use dimension. Furthermore, the experts agreed on the importance of Web site planning and development skills, which is ranked number four. However, this was at the bottom of the list of information skills that college students had.

\subsubsection{Differences in levels of basic information abilities based on background variables for students}

The results of the interaction analysis of the background data for college students, including school type, gender and school year and the five dimensions of information application abilities yielded the following results shown in Table 4.

\section{Table 4}

Differences in basic information application ability levels based on different background variables for college students

\begin{tabular}{|c|c|c|c|c|c|}
\hline & Office use & $\begin{array}{l}\text { Layout and } \\
\text { graphic design }\end{array}$ & $\begin{array}{c}\text { Web page } \\
\text { development }\end{array}$ & $\begin{array}{l}\text { Computers } \\
\text { and the } \\
\text { Internet }\end{array}$ & Digital media \\
\hline $\begin{array}{l}\text { School } \\
\text { type }\end{array}$ & $\begin{array}{c}\text { University and } \\
\text { college }> \\
\text { Technology } \\
\text { and vocational } \\
\text { school }\end{array}$ & $\begin{array}{c}\text { University and } \\
\text { college male }> \\
\text { Technology } \\
\text { and vocational } \\
\text { school male } \\
\text { University and } \\
\text { college female } \\
>\text { Technology } \\
\text { and vocational } \\
\text { school female }\end{array}$ & $\begin{array}{c}\text { University and } \\
\text { college }> \\
\text { Technology and } \\
\text { vocational } \\
\text { school }\end{array}$ & $\begin{array}{c}\text { University and } \\
\text { college }> \\
\text { Technology } \\
\text { and vocational } \\
\text { school }\end{array}$ & $\begin{array}{c}\text { University and } \\
\text { college }> \\
\text { Technology } \\
\text { and vocational } \\
\text { school }\end{array}$ \\
\hline Gender & Female $>$ Male & $\begin{array}{c}\text { University and } \\
\text { college female } \\
>\text { University } \\
\text { and college } \\
\text { male } \\
\text { Technology } \\
\text { and vocational } \\
\text { school females } \\
\text { and technology } \\
\text { and vocational } \\
\text { school males } \\
\text { n.s. }\end{array}$ & $\begin{array}{l}\text { Males and } \\
\text { females n.s. }\end{array}$ & Male $>$ Female & $\begin{array}{c}\text { Males and } \\
\text { females n.s. }\end{array}$ \\
\hline $\begin{array}{l}\text { School } \\
\text { year }\end{array}$ & $\begin{array}{c}4>1,4>2,3>1, \\
2>1\end{array}$ & $4>1,3>1$ & $\begin{array}{c}4>1,4>2,3>1, \\
3>2\end{array}$ & $\begin{array}{c}4>1,4>2,3>1, \\
2>1\end{array}$ & $4>1,3>1,2>1$ \\
\hline
\end{tabular}

Note: n. s. p>.05 
University and college students were more proficient than their technology and vocational school counterparts in the five main information ability dimensions. Regarding layout and graphic design, male and female university and college students showed significantly superior skills to their male and female technology and vocational school counterparts respectively. Females are generally more competent than males, except when considering the dimension of computers and the Internet, in which males showed significantly higher skills than females. This is especially true for the layout and graphic design and Office use dimensions. There is no significant difference between Web page development and digital media use between genders. The basic information skills of students in higher school years are generally stronger than those of their younger counterparts, with juniors and senior showing superior skills in every aspect.

\section{Conclusion and suggestions}

\subsection{Conclusion}

\subsubsection{Establishing college student basic information ability indicators for employability}

The researcher developed five dimensions (Office use, Layout and graphic design, Web page development, Computers and the Internet, and Digital media), 10 items, and 58 indicators for the basic information abilities for employability among college students.

\subsubsection{Difference between self-perceived information skills and those required by experts}

The college students who participated in the study did not reach the experts' expectations regarding data spreadsheets, Web site planning and development, and digital layout selfassessments. The experts believe that skills in these three areas can be improved.

\subsubsection{Establishment of college students' information skills}

Most of the basic information skills in the dimensions and items, such as Office use skills and the use of computers and the Internet, are formed in college students' sophomore or junior years; knowledge of digital media and layout and graphic design are formed or already formed in their sophomore years; and Web page development skills are developed in their junior years.

\subsection{Suggestions}

\subsubsection{Improve data spreadsheet abilities in the office use dimension}

The experts unanimously agreed that the Office use dimension is the most essential information skill for employment; this is especially true for the data spreadsheet item. In reality, however, the average score of the data spreadsheet item for college students placed in the lower third ranking of the ten items. This shows that the data spreadsheet skills of college students are lower than what the experts expect. Performance and 
numerical analysis and application are vital in the workplace. The research suggests that computer skills for Office use should be incorporated as a graduation threshold for information abilities college students must possess, and college students' abilities to use data spreadsheets should be enhanced.

\subsubsection{Design courses and workshops based on school years in which college students are expected to develop certain information skills}

The results of the study can be used to infer the differences in information skills for different school years as well as the school years in which skills are developed. Some dimensions of information skills are fully developed in students' sophomore and junior years. To allow students the opportunity to continue improving the information skills for various dimensions, schools should offer advanced courses, workshops, and links with industry workplace internships during the different establishment periods for dimension abilities. For example, to develop better and more comprehensive Web page development abilities, schools should offer advanced courses or practicums to junior students in their second semester or senior students in their first semester. Regarding layout and graphic design and digital media, by contrast, sophomores should be provided opportunities to improve their artistic sense in their sophomore year, and further improve their design strengths. Office use abilities and use of computers and the Internet can be divided into beginner and advance levels, allowing students' information learning to develop by stages.

\subsubsection{Integrate course instruction for information abilities with similar elements to advance learning results and produce value-added pieces}

Research results have shown that females are superior in skills for Office use and layout and graphic design than their male counterparts. It is proposed that these two dimensions are more associated to graphic design concepts and involve more symbols, texts, and static images. Thus, the two possess the effects of transformation in the identical elements theory within learning transfer. Consequently, if females have superior learning achievements in Office use, they can easily show better performance in layout and graphic design, which is similar. Education design can be further incorporated, integrating text processing and powerpoint, courses with image design and digital layout. Furthermore, Web page development, which includes design and planning elements, can be integrated with image layout. These integrations can further advance the learning achievements for information skills and improve the depth of products and pieces.

\subsubsection{Introducing an information skill testing mechanism and implementing regular information testing can maintain the stability and improvement of student abilities}

Information skill levels should be routinely monitored to ensure stable basic strengths and be more applicable to the challenge of increasingly innovative new technologies. A testing mechanism within the school that presents information ability certification to those who pass can provide the same effect as a certification from outside computer cram school market sources, especially if the students have passed test items screened for validity and reliability and practical test verification. Certifications achieved during school periods were demonstrated as being accepted and trusted by industry human resource managers during the preparatory period interviews. Furthermore, because 
information skills of various dimensions stagnate in students' sophomore and junior years and do not continue to show significant improvement, a regular information testing mechanism can help spur further improvement within already maintained stability.

\section{References}

Broad, M. L. (1997). Transferring learning to the workplace: Seventeen case studies from the real world of training. Alexandria, VA: American Society for Training and Development.

Chang, C.-H. (1989). Educational psychology. Taipei,Taiwan:Tunghua press.

Chang, C.-H. (2008). Educational psychology: Theory and practice of three orientation. Taipei,Taiwan:Tunghua press.

Chen, C.-H. (2008, October 25). Students have more license that will be more easy successful for emloyment. United Daily News.

Chi, C.-H., \& Sun, C.-L. (2009). Implementing the university teaching excellence program. Journal of Educational Administration and Evaluation, 8, 1-22.

Chou, C.-M. (2009). Commentary on modern theory of learning transfer. China Electric Power Education, 150, 20-22.

Curtin, P. (2004). Employability skills for the future. In J. Gibb (Ed.), Generic skills in vocational education and training: research readings (pp. 38-52). Adelaide, South Australia: National Centre for Vocational Education Research.

Harvey, L., Locke, W., \& Morey, A. (2002). Enhancing employability, recognising diversity. London Universities UK.

Lio, M.-C., Chiou, J.-R., \& Hu, J.-L. (2006). Enhance the employability of force in the formal education: Graduating university and college student employability survey report. Taipei,Taiwan: National Youth Commission, Executive Yuan.

Pool, L. D., \& Sewell, P. (2007). The key to employability: Developing a practical model of graduate employability. Education and Training, 49(4), 277-289.

Sun, C.-L. (2005). The expansion of higher education policy analysis: The plight and transformation. Paper presented at 2005 Taiwan Education Conference: National Taitung University, Taitung, Taiwan.

Tsai, F.-Y. (2002). A study of the effect on learning transfer by thinking styles in internet project-based learning environment. Unpublished master's thesis, National University of Tainan, Tainan, Taiwan. 